\title{
PENGARUH MODEL PEMBELAJARAN BERBASIS MASALAH DENGAN PEMBEKALAN PENGETAHUAN AWAL TERHADAP KETERAMPILAN PROSES SAINS PESERTA DIDIK SMA
}

\author{
Nurul Hikmawati, Sutrio, Hikmawati \\ Program Studi Pendidikan Fisika \\ Universitas Mataram \\ Jalan Majapahit No. 62, Mataram \\ Email: hikmawatianyar@gmail.com
}

\begin{abstract}
This study aims to determine the effect of problem based learning model with debriefing prior knowledge of the science process skills of learners. This research is a quasi experimental research using nonequivalent control group design. The population in this study is all students of class XI IPA SMAN 1 Montong Gading. The sampling of the research using saturated sampling technique, so that the selected class XI IPA 1 as the experimental class will be given treatment in the form of problem-based learning model with initial knowledge knowledge and class XI IPA 2 as the control class to be given treatment in the form of problembased learning model. Data collection of science process skills using observation techniques on the observation sheet. Hypothesis test using t-pooled variance test obtained $t_{\text {count }}$ value is greater than $t_{\text {table. }}$ The result of the research shows that the use of problem-based learning model with prior knowledge sharing influences the science process skill of SMA students.
\end{abstract}

Keywords: Problem-based learning, briefing prior knowledge, skills process.

\section{PENDAHULUAN}

Pendidikan memegang peranan penting untuk kemajuan suatu bangsa. Dalam lingkup pendidikan, model atau metode pembelajaran merupakan salah satu faktor yang berpengaruh dalam proses pembelajaran. Keberhasilan pembelajaran sangat bergantung pada kemampuan guru mengolah pembelajaran. Untuk mencapai keberhasilan pembelajaran sangat dipengaruhi adanya model pembelajaran yang diterapkan. Akan tetapi kenyataanya banyak guru yang masih mengajar dengan mengandalkan model pembelajaran konvensional seperti dalam pembelajaran fisika.

Fisika merupakan salah satu cabang IPA yang mendasari perkembangan teknologi maju dan konsep hidup harmonis dengan alam. Fisika merupakan pengetahuan, gagasan dan konsep tentang alam sekitar yang diperoleh dari pengalaman melalui pengamatan dan diaplikasikan dalam dunia nyata (Prihatiningtyas, Prastowo \& Jatmiko, 2013). Oleh karena itu, dalam diri peserta didik sebaiknya ditumbuhkan kesadaran agar melihat fisika bukan hanya sebagai kegiatan akademik, tetapi lebih sebagai cara untuk memahami dunia tempat mereka hidup.
Berdasarkan hasil observasi dan wawancara di SMAN 1 Montong Gading, masih ditemukan proses pembelajaran yang berpusat terhadap guru sehingga keaktifan peserta didik di kelas cenderung rendah. Umumnya peserta didik dituntut untuk lebih banyak mempelajari konsep-konsep dan prinsip-prinsip fisika yang hanya terdapat dalam buku pelajaran. Sehingga, belajar fisika hanya diartikan sebagai pengenalan sejumlah konsepkonsep dan penyelesaian dalam bidang fisika saja. Selain itu, kegiatan praktikum jarang dilakukan. Terbukti dari ruangan laboraturium yang digunakan sebagai temapat kegiatan belajar mengajar. Hal inilah yang menyebabkan pelajaran fisika sering dianggap sebagai pelajaran yang sulit dan membosankan. Kesimpulan ini sejalan dengan pendapat Setyowati, Subali \& Mosik (2011) yang mengatakan bahwa mata pelajaran fisika dirasakan sulit oleh peserta didik, karena sebagian besar peserta didik belum mampu menghubungkan antara materi yang dipelajari dengan pengetahuan yang digunakan.

Proses pembelajaran konvensional yang diterapkan mengakibatkan pencapaian kompetensikompetensi yang mencakup aspek pengetahuan, 
keterampilan, sikap, dan nilai-nilai yang diwujudkan dalam kebiasaan berpikir dan bertindak yang disebut hasil belajar kurang maksimal (Trianto, 2007). Seharusnya dalam proses pembelajaran dapat membantu peserta didik belajar efektif sehingga akan berdampak pada hasil belajar fisika maupun peningkatan kemampuan berpikir dan bertindak berdasarkan pengetahuan sains yang dimiliknya, atau lebih dikenal dengan keterampilan proses sains.

Keterampilan proses sains merupakan suatu pondasi yang diperlukan pada saat proses penyelesaian masalah ilmiah (Devi, 2010). Pembelajaran dengan mengembangkan keterampilan proses memudahkan peserta didik untuk menemukan suatu konsep, prinsip atau teori untuk mengembangkan konsep yang telah ada sebelumnya, ataupun untuk melakukan penyangkalan terhadap suatu penemuan (Azizirrahim, Sutrio \& Gunawan, 2015). Dengan demikian peserta didik dididik dan dilatih untuk terampil dalam memperoleh dan mengolah informasi melalui aktivitas berpikir dengan mengikuti prosedur (metode) ilmiah, seperti kemampuan mengamati, mengklasifikasi, menafsirkan, meramalkan, menerapkan, merencanakan penelitian dan mengkomunikasikan (Hosnan, 2016). Karena pada hakekatnya keterampilan proses sains dapat membuat peserta didik kreatif dan aktif dalam proses pembelajaran (Widayanto, 2009; Djamarah \& Bukhari 2000).

Berdasarkan kenyataan tersebut, maka perlu dilakukan perbaikan dalam kegiatan pembelajaran agar keterampilan proses peserta didik dalam fisika meningkat. Salah satu alternatif pemecahan masalahnya adalah dengan menggunakan model pembelajaran berbasis masalah. Pembelajaran berbasis masalah dapat melatih serta meningkatkan keterampilan proses peserta didik (Prima \& Kurniawati, 2011), karena dengan keterampilan proses yang dimiliki peserta didik dapat memecahkan masalah yang dihadapi dalam kehidupan dan memberi bekal peserta didik untuk membentuk konsep sendiri dengan cara bagaimana mempelajari sesuatu telah terbukti pada penelitian yang dilakukan oleh (Suardani, Swasta \& Widiyanti, 2014). Pendapat ini didukung oleh Sani (2014); Duch (dalam Heryanti \& Habibi, 2014); Taufiq (dalam Gunada, Sahidu dan Sutrio, 2015) mengungkapkan bahwa model pembelajaran berbasis masalah menghubungkan konten dan aplikasi dunia nyata membantu peserta didik belajar tentang sains dan dapat menerapkan pengetahuan yang sesuai. Oleh karena itu, peran guru dalam proses pembelajaran model ini adalah sebagai pembimbing peserta didik dalam melakukan penyelidikan bukan memberikan konsep (Arends, 2007).

Pengoptimalan penggunaan model pembelajaran berbasis masalah di dalam kelas tidak terlepas dari pengetahuan awal peserta didik. Pengetahuan awal akan membantu proses pembelajaran jika peserta didik distimulus untuk mengingat memori jangka panjang yang dimiliki (Darma, 2013; Ismaimuza, 2011). Sehingga peneliti tertarik untuk menambahkan pembekalan pengetahuan awal sebelum keseluruhan fase dari model pembelajaran berbasis masalah. Oleh karena itu, fase-fase pembelajaran yang digunakan oleh peneliti adalah pemberian pembekalan pengetahuan awal, menemukan masalah, membangun struktur kerja, menetapkan masalah, mengumpulkan informasi, merumuskan solusi, menentukan solusi terbaik dan menyajikan solusi (Abidin, 2014) dimodifikasi oleh peneliti. Dalam pembelajaran ini peserta didik diberikan kesempatan untuk mempersiapkan pengetahuan awal yang dimiliki untuk mempermudah proses pembelajaran sehingga dapat berdampak pada peningkatan keterampilan proses sains. Hal ini mengindikasikan bahwa pengetahuan awal setidak-tidaknya sebagai bekal ajar awal yang cukup menentukan perolehan belajar (Prastiti, 2007).

Berdasarkan paparan uraian di atas, peneliti tertarik melakukan penelitian untuk mengetahui seberapa besar "Pengaruh Model Pembelajaran Berbasis Masalah (PBM) dengan Pembekalan Pengetahuan Awal terhadap Keterampilan Proses Sains Peserta Didik SMA.”

\section{METODE PENELITIAN}

Jenis penelitian ini adalah quasi-experiment dengan desain non-equivalent control group design. Sebelum diberi perlakukan kedua kelompok sampel dilakukan observasi awal keterampilan proses sains. Selanjutnya kelas eksperimen diberikan perlakuan dengan model pembelajaran berbasis masalah dengan pembekalan pengetahuan awal dan kelas kontrol diberi perlakuan berupa model 
pembelajaran pembelajaran berbasis masalah. Sesudah perlakuan, kedua kelas lakukan kembali observasi keterampilan proses sains.

Penelitian ini terdapat 3 variabel yaitu variabel bebas yaitu model pembelajaran berbasis masalah dengan pembekalan pengetahuan awal, variabel terikat yaitu keterampilan proses sains, variabel kontrol yaitu materi ajar yang diajarkan, guru yang mengajar, dan instrumen penilaian pada kelas eksperimen dan kontrol. Populasi dalam penelitian ini adalah seluruh siswa kelas XI IPA di SMAN 1 Montong Gading tahun ajaran 2016/2017. Sedangkan sampel digunakan dipilih dengan menggunakan teknik sampling jenuh. Teknik pengumpulan data keterampilan proses sains berupa lembar observasi. Setelah itu, untuk mengetahui peningkatan nilai kedua kelas sebelum dan sesudah diberi perlakuan, digunakan uji t polled varians.

Selain uji hipotesis, dilakukan juga uji NGain. Sundayana (2014) menyatakan bahwa uji skor gain dilakukan untuk mengetahui seberapa besar peningkatan kemampuan berpikir kritis dengan kriteria terlihat pada Tabel. 1.
Tabel 1 Interpretasi Skor Gain

\begin{tabular}{lll}
\hline No. & Interval & Kriteria \\
\hline 1 & $0,70 \leq \mathrm{g} 1,00$ & Tinggi \\
2 & $0,30 \leq \mathrm{g}<0,70$ & Sedang \\
3 & $0,00<\mathrm{g}<0,30$ & Rendah \\
\hline
\end{tabular}

\section{HASIL DAN PEMBAHASAN}

Ranah yang dinilai dalam penelitian ini adalah keterampilan proses sains. Untuk itu keterampilan proses sains diukur dengan lembar observasi berisi rekapitulasi nilai keterampilan proses sains harian. Keterampilan yang diukur adalah keterampilan proses sains dengan 7 indikator. Adapun kemampuan keterampilan proses sains peserta didik sebelum diberikan perlakuan terlihat dari hasiil observasi awal, dan keteramplan proses sains setelah diberikan perlakuan terlihat dari rata-rata hasil observasi harian.

Observasi awal dilakukan untuk mengetahui homogenitas serta normalitas sampel Adapun hasil observasi dapat dilihat pada Gambar 1.

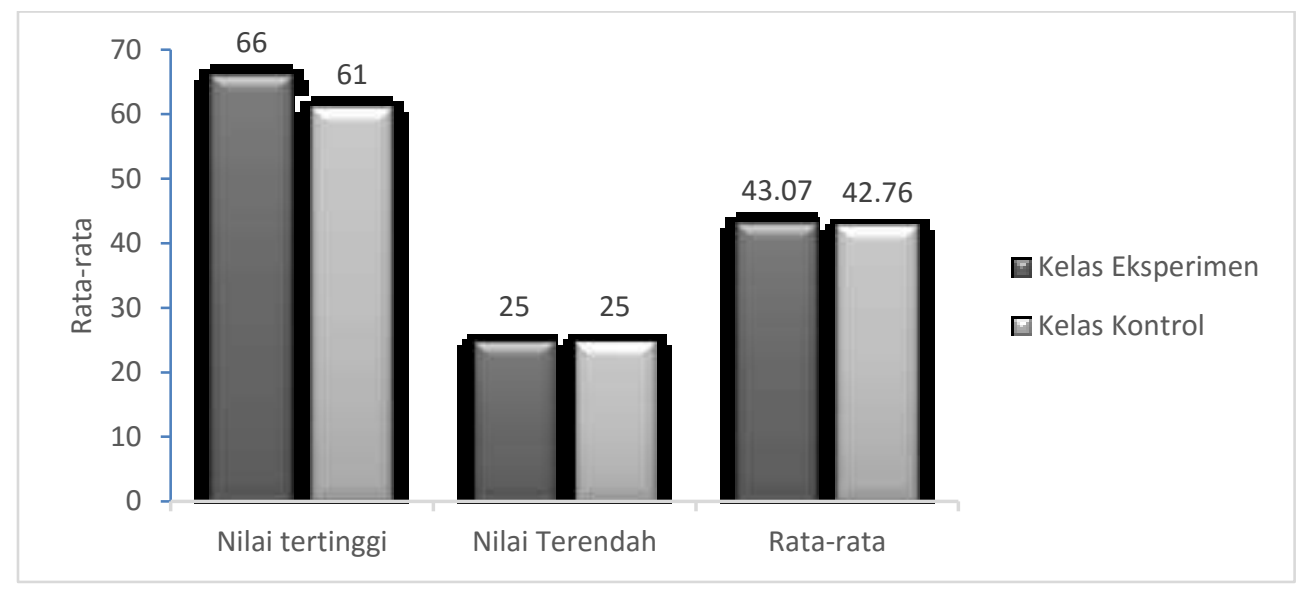

Gambar 1 Histogram Perbandingan KPS Awal Peserta Didik

Dalam Gambar 1 di atas terlihat bahwa nilai tertinggi untuk kelas eksperimen adalah 66 dan kelas kontrol adalah 61 sedangkan untuk nilai terendah pada kelas eksperimen adalah 24 begitupun untuk kelas kontrol. Dengan rata-rata nilai kelas eksperimen 43.07 dan rata-rata nilai kelas kontrol 42.76.

Data keterampilan proses akhir yang diperoleh pada penelitian ini adalah data setelah diberikan perlakuan. Rekapitulasi rata-rata akhir dilakukan untuk mengetahui normalitas dan hipotesis penelitian. Adapun hasil rekapitulasi ratarata observasi akhir dapat dilihat pada Gambar 2. Dalam Gambar 2 di bawah terlihat bahwa nilai tertinggi untuk kelas eksperimen dan kelas kontrol adalah adalah 93 sedangkan untuk nilai terendah pada kelas eksperimen dan kontrol adalah 39. Dengan rata-rata nilai kelas eksperimen 69.81 dan rata-rata nilai kelas kontrol 62.45 . 


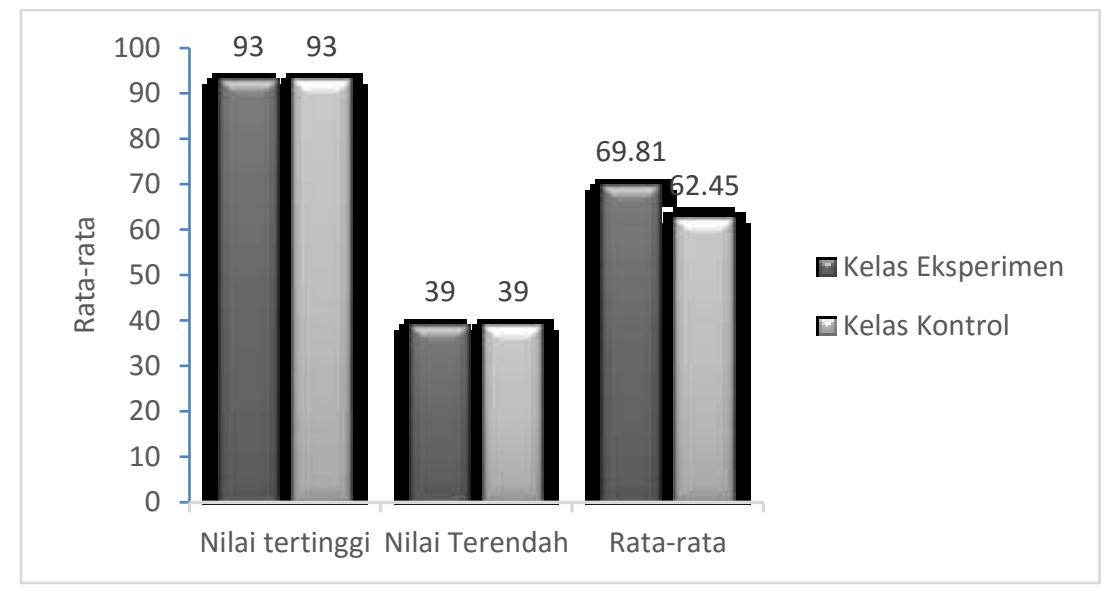

Gambar 2 Histogram Perbandingan Observasi Akhir Peserta Didik

Pengujian data untuk kelas eksperimen dan kelas kontrol diawali dengan uji homogenitas kedua data, yang dilanjutkan dengan uji normalitas, dan terakhir uji hipotesis menggunakan uji-t polled varians. Dari uji homogenitas data untuk observasi awal yang telah dilakukan didapat

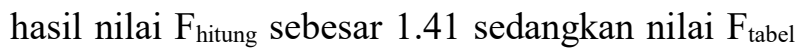
1.78 dengan taraf signifikan 0,05 . Sehingga $F_{\text {hitung }}$ $<\mathrm{F}_{\text {tabel }}$ yang berarti data tes awal kedua kelas adalah homogen.

Berikutnya dilakukan uji normalitas data observasi awal dan akhir pada masing-masing kelas. Untuk hasil observasi awal didapatkan nilai $\chi_{\text {hitung }}^{2}$ sebesar 4.58 untuk kelas eksperimen dan 4,53 untuk kelas kontrol. Nilai $\chi^{2}{ }_{\text {tabel }}$ dengan taraf signifikan 0,05 untuk kelas eksperimen dan kelas kontrol sebesar 12,59. Sehingga dari kedua data tersebut dapat dilihat bahwa $\chi^{2}{ }_{\text {hitung }}<$ $\chi_{\text {tabel }}^{2}$ yang berarti data tes awal untuk kedua kelas berdistribusi normal. Observasi akhir keterampilan proses sains nilai $\chi_{\text {nitung }}^{2}$ untuk kelas eksperimen sebesar 8,76 dan untuk kelas kontrol sebesar 1,95 Nilai $\chi_{\text {tabel }}^{2}$ dengan taraf signifikan 0,05 untuk kedua kelas adalah 12,59 sehingga data KPS kedua kelas terdistribusi normal. Berdasarkan perhitungan tersebut disimpulkan bahwa data keterampilan proses sains berdistribusi normal pada untuk kelas eksperimen dan kelas kontrol.

Untuk mengetahui adanya pengaruh model pembelajaran berbasis masalah dengan pembekalan pengetahuan awal terhadap keterampilan proses sains peserta didik dilakukan uji hipotesis. Uji hipotesis menggunakan statistik parametrik karena data homogen dan terdistribusi normal. Uji hipotesis yang digunakan adalah uji-t polled varians karena sampel pada penelitian ini berbeda $\left(n_{1} \neq n_{2}\right)$. Hasil uji statistik yang dilakukan, didapatkan nilai $t_{\text {hitung }}$ sebesar 2,05. Nilai $t_{\text {hitung }}$ tersebut lebih besar dibandingkan nilai $t_{\text {tabel, }}$ yaitu 1,99 pada taraf signifikan 0,05. Sehingga penggunaan model pembelajaran berbasis masalah dengan pembekalan pengetahuan awal berpengaruh terhadap keterampilan proses sains peserta didik SMA.

Indikator pengukuran keterampilan proses sains diukur dari kemampuan observasi, klasifikasi, menafsirkan, meramalkan, merencanakan percobaan, menerapkan konsep dan komunikasi. Berikut secara lebih rinci perbedaaan tujuh keterampilan proses sains antara kelas eksperimen dan kelas kontrol dapat dilihat pada gambar 3. 


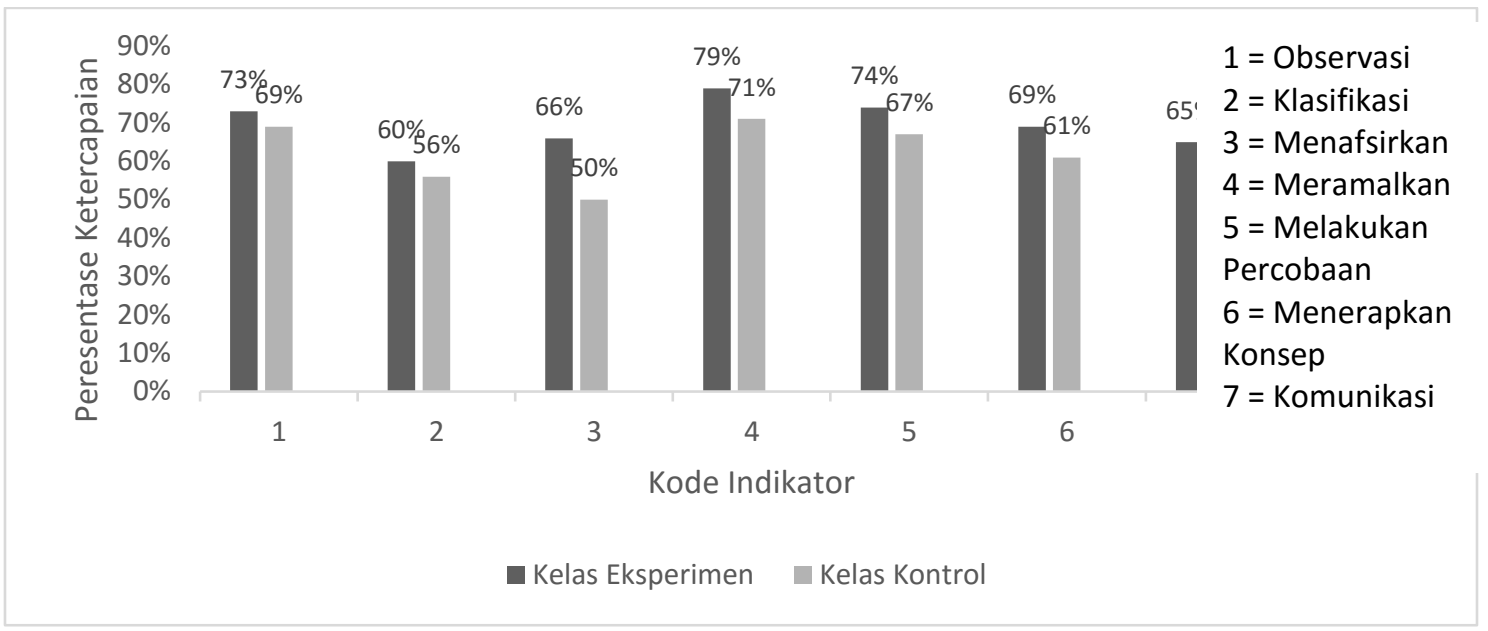

Gambar 3 Persentase Keberhasilan Tiap Indikator KPS

Gambar 3 menunjukkan perbedaan persentase keberhasilan yang dicapai kelas eksperimen dan kelas kontrol. Persentase keberhasilan keterampilan observasi menunjukkan nilai sebesar $73 \%$ untuk kelas eksperimen dan $69 \%$ untuk kelas kontrol. Keterampilan klasifikasi menunjukkan perbedaan keberhasilan tercapaian sebesar $60 \%$ untuk kelas eksperimen dan kelas kontrol sebesar $56 \%$. Keterampilan menafsirkan menujukkan nilai $66 \%$ untuk kelas eksperimen sedangkan kelas kontrol menunjukkan perbedaan yang cukup jauh yaitu 50\%. Keterampilan meramalkan untuk kelas eksperimen dan kontrol sebesar $79 \%$ dan $71 \%$. Keterampilan melakukan percobaan memiliki perbedaan sebesar $8 \%$ dengan nilai $79 \%$ dan $71 \%$ untuk kelas eksperimen dan kelas kontrol. Begitupun keterampilan menerapkan konsep sebesar $69 \%$ dan $61 \%$ untuk kelas eksperimen dan kelas kontrol. Sedangkan keteramplian terakhir yaitu komunikasi memiliki perbedaan yang relative kecil sebesar 1\% dengan nilai kelas kontrol dan eksperimen yaitu $64 \%$ dan
65\%. Hal ini disebabkan karena model pembelajaran yang digunakan menuntut peserta didik untuk berdiskusi sehingga terciptanya komunikasi yang kondusif antar peserta didik. Handhika (2007) berpendapat bahwa, meskipun pembelajaran yang digunakan sama akan tetapi metode yang digunakan berbeda akan memberikan pengaruh yang berbeda terhadap ketercapaian peserta didik.

Selain melakukan uji hipotesis dan perhitungan persentase keberhasilan, peneliti juga ingin mengetahui sejauh mana peningkatan yang dialami kedua kelas secara lebih terperinci terkait hubungan nilai kelas kontrol dan kelas eksperimen untuk persentase kenaikan keterampilan proses sains setiap indikator. Perbandingan peningkatan keterampilan proses sains pada materi fluida dalam Gambar 4. Terdapat 7 indikator keterampilan proses sains. Setiap indikator dianalisis ketercapaiannya berdasarkan perolehan skor observasi awal dan akhir. 


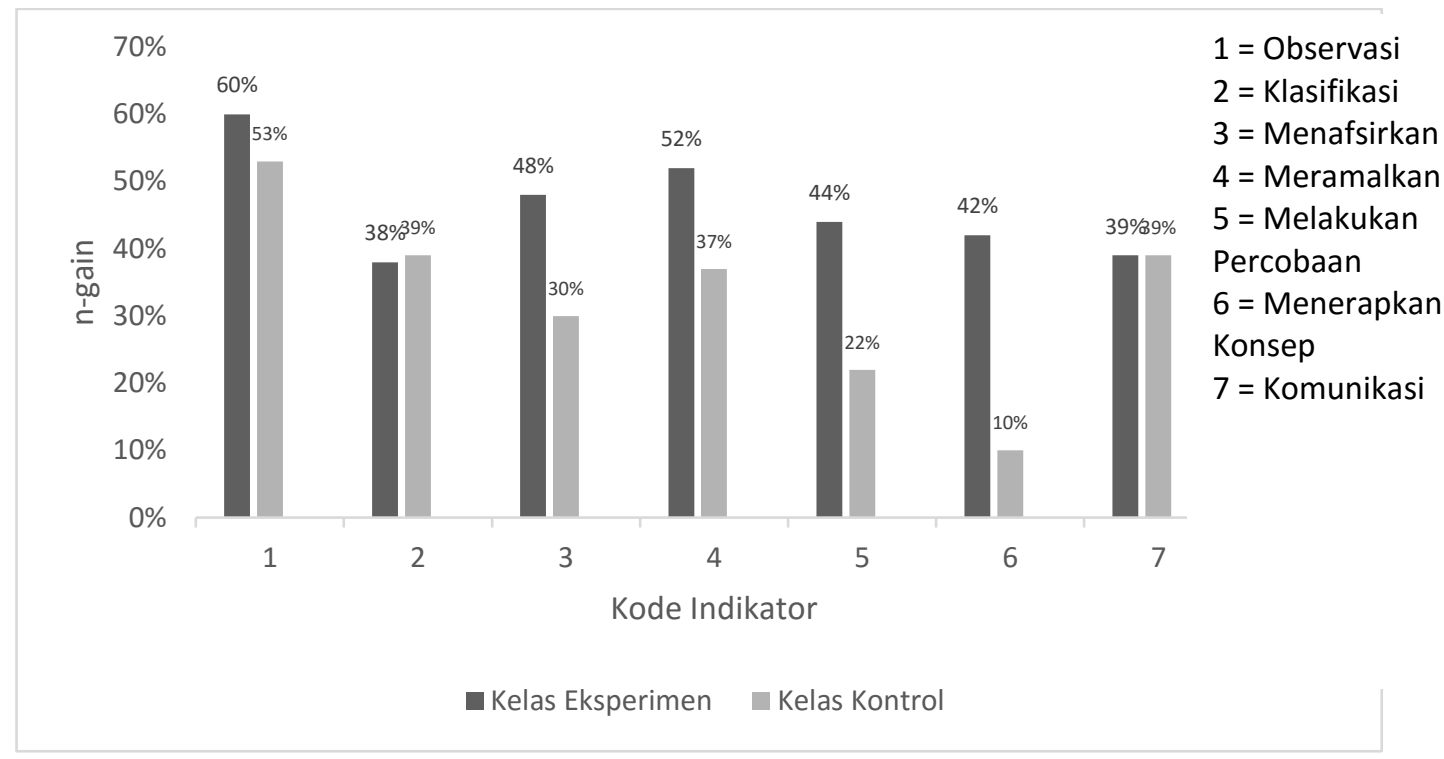

Gambar 4 Perbandingan Nilai N-gain Per Indikator Keterampilan proses Sains

Berdasarkan analisis pada Gambar 4 dapat diketahui bahwa perolehan persentase N-gain secara umum kelas eksperimen lebih tinggi dibandingkan kelas kontrol. Uraian per indikatornya sebagai berikut:

\section{Keterampilan Observasi}

Observasi dapat dikatakan sebagai keterampilan sederhana ketika peserta didik dapat menemukan permasalahan-permasalahan yang diberikan dalam LKPD. Observasi juga dapat menjadi keterampilan yang kompleks karena melalui observasi peserta didik dapat menemukan permasalahan utamanya. Analisis hasil observasi dari penelitian yang dilakukan terhadap hasil LKPD terdapat peningkatan dari kedua kelas. Nilai faktor $\mathrm{n}$ gain keteranpilan observasi termasuk dalam kategori sedang yaitu $60 \%$ untuk kelas eksperimen dan 53\% untuk kelas kontrol. Terlihat dari gambar 4 bahwa indikator observasi merupakan n-gain tertinggi dari indikator yang lain karena indikator observasi merupakan tuntutan fase awal baik untuk kelas eksperimen maupun kontrol.

\section{Keterampilan Klasifikasi}

Keterampilan klasifikasi ialah keterampilan mengelompokkan yang dalam penelitian ini peserta didik dituntut agar dapat mengelompokkan permasalahan yang sesuai dengan permasalahan utama pada LKPD. Nilai faktor $\mathrm{n}$ gain keterampilan klasifikasi termasuk dalam kategori sedang yaitu $38 \%$ untuk kelas eksperimen dan 39\% untuk kelas kontrol. Terlihat bahwa kedua kelas mengalami peningkatan yang hampir sama besar selisihnya sebesar $1 \%$. Penyebabnya karena kedua kelas menggunakan model pembelajaran yang memiliki fase sama yaitu fase menemukan masalah yang mana dalam fase tersebut peserta didik dituntut untuk teliti dalam menemukan permasalahan.

\section{Keterampilan Menafsirkan}

Keterampilan menafsirkan ialah keterampilan menentukan variabel dan langkah yang tepat untuk menemukan solusi terbaik. Pemberian pembekalan pengetahuan awal kepada kelas eksperimen mendorong peserta didik untuk menentukan pilihan terbaik dengan menghubungkan dengan konsep awal yang dimiliki. Akibatnya kelas eksperimen mengalami peningkatan yang lebih besar dibandingkan kelas kontrol. Analisis hasil menafsirkan dari penelitian yang dilakukan terhadap hasil LKPD terdapat peningkatan dari kedua kelas. Nilai faktor $\mathrm{n}$ gain keterampilan menafsirkan termasuk dalam kategori sedang yaitu $48 \%$ untuk kelas eksperimen dan 30\% untuk kelas kontrol.

\section{Keterampilan Meramalkan}

Keterampilan meramalkan menuntut peserta didik memprediksi permasalahan yang dikemukakan atau biasa disebut berhipotesis. Nilai faktor $\mathrm{n}$ gain keteranpilan observasi termasuk dalam kategori sedang yaitu $52 \%$ untuk kelas eksperimen dan 37\% untuk kelas kontrol. Terlihat bahwa kelas eksperimen mengalami peningkatan yang lebih besar, pembekalan pengetahuan awal 
yang diberikan merupakan suatu hal yang fundamental yang harus dimiliki peserta didik dalam menuyun hipotesis.

\section{Keterampilan Merencanakan Percobaan}

Peserta didik dituntut untuk dapat merangkai alat dan bahan yang akan digunakan dalam kegiatan eksperimen. Keterampilan merencanakan percobaan ini diukur langsung oleh observer selama proses pembelajaran. Nilai faktor $\mathrm{n}$ gain keterampilan merencanakan percobaan termasuk dalam kategori sedang untuk kelas eksperimen dan kategori rendah untuk kelas kontrol yaitu 44\% untuk kelas eksperimen dan 22\% untuk kelas kontrol. Terlihat bahwa kelas eksperimen mengalami peningkatan yang lebih besar, hal ini disebabkan karena adanya perlakuan eksternal berupa pembekalan pengetahuan awal yang memotivasi untuk lebih aktif dalam proses penyelidikan.

\section{Keterampilan Menerapkan Konsep}

Analisis dari indikator menerapkan konsep terdapat peningkatan dari kedua kelas. Nilai faktor n gain keteranpilan observasi yaitu $42 \%$ untuk kelas eksperimen termasuk dalam kategori sedang dan $10 \%$ untuk kelas kontrol termasuk dalam kategori rendah. Terlihat bahwa kelas eksperimen lebih unggul karena telah memiliki bekal pengetahuan untuk menyelesaikan permasalahan yang muncul dengan tepat. Rahmawati, Nugroho \& Putra (2014) mengemukakan ketercapaian keterampilan proses sains dipengaruhi oleh pengetahuan yang dimiliki peserta didik.

\section{Keterampilan Komunikasi}

Keterampilan komunikasi merupakan aspek yang sangat penting untuk menyampaikan ide, fakta dan konsep. Analisis observasi dari penelitian yang dilakukan langsung oleh observer terdapat peningkatan dar kedua kelas. Nilai faktor n gainnya mengalami peningkatan yang sama sebesar 39\% karena fase akhir dari model pembelajaran yang digunakan peserta didik dituntut untuk menyajikan hasil pemecahan masalah yang disimpulkan. Namun, secara rata-rata peningkatan keterampilan proses sains pada kelas eksperimen lebih tinggi dibandingkan kelas kontrol. Dimana pada kelas eksperimen rata-rata peningkatannya sebesar $47 \%$ sedangkan peningkatan kelas kontrol adalah 34\%.
Keterampilan proses sains dapat meningkat melalui model pembelajaran berbasis masalah dengan pembekalan pengetahuan awal karena model pembelajaran berbasis masalah ditambahkan dengan pemberian pembekalan pengetahuan awal memberikan kesempatan kepada peserta didik untuk lebih aktif dan termotivasi mengembangkan kemampuan yang dimiliki untuk menemukan konsep ataupun teori yang sedang dipelajari. Dari hasil penelitian juga menggambarkan keterampilan proses sains peserta didik berbeda. Kelas eksperimen lebih mampu menunjukkan keterampilan proses sains yang dimiliki. Hal ini sesuai dengan pendapat dari Muamar, Hardjono \& Gunawan, 2015; Irawati, 2014, Suliyono, 2013 yang mengatakan bahwa peserta didik dengan pengetahuan awal tinggi lebih mampu menyelesaikan fase-fase pembelajaran maupun tujuan pembelajaran. Sehingga dapat dikatakan bahwa peserta didik kelas eksperimen memiliki keterampilan proses sains yang baik.

Kesimpulan diatas didukung oleh hasil penelitian yang dilakukan oleh Prima (2011) yang menyatakan bahwa pembelajaran berbasis masalah lebih dapat meningkatkan keterampilan proses sains. Wahyudi, Marjono \& Harlita (2015) berpendapat bahwa model pembelajaran berbasis masalah berpengaruh terhadap rata-rata nilai keterampilan proses sains peserta didik. Model pembelajaran berbasis masalah sangat baik untuk meningkatkan keterampilan proses sains peserta didik karena pembelajaran konvensional kurang mengakomodssi keterampilan proses sains, sejalan dengan pendapat Meyers, Washburn \& Dyer (2004) bahwa keterampilan proses sains dapat dikuasai peserta didik jika keterampilan berfikir tingkat tinggi didapatkan peserta didik sedangkan keterampilan berfikir tingkat tinggi dapat didapatkan melalui model pembelajaran berbasis masalah (Masek \& Sulaiman, 2011). Pada dasarnya keterampilan proses sains dapat tumbuh secara efektif apabila peserta didik dibiasakan untuk berlatih karena hubungan antara stimulus dan respon akan kuat apabila dilakukan dengan latihan. Oleh karena itu, pembelajaran berbasis masalah dengan pembekalan pengetahuan awal dapat menjadi alternatif untuk mengoptimalkan keterampilan proses sains peserta didik. 


\section{PENUTUP}

Berdasarkan hasil dan pembahasan dapat disimpulkan bahwa terdapat pengaruh model pembelajaran berbasis masalah dengan pembekalan pengetahuan awal terhadap keterampilan proses sains peserta didik SMA.

\section{REFERENSI}

Abidin, Y. (2014). Desain Sistem Pembelajaran dalam Konteks Kurikulum 2013. Bandung: PT Refika Aditama.

Azizirrahim, E., Sutrio, S., \& Gunawan, G. (2015). Penerapan Pendekatan Keterampilan Proses Sains dalam Model Pembelajaran Guided Discovery untuk Meningkatkan Hasil Belajar IPA Fisika pada Siswa Kelas VIIA SMPN 8 Mataram Tahun Ajaran 2015/2016. Jurnal Pendidikan Fisika dan Teknologi, 1(2), 272275.

Arends, R.I. (2007). Learning to Teach 7th Edition. USA: The McGraw-Hill Companies, Inc.

Darma, N.I., Sadra, W.I., dan Sariyasa. (2013). Pengaruh Pendidikan Matematika Realistik terhadap Pemahaman Konsep dan Daya Matematika Ditinjau dari Pengetahuan Awal Siswa SMP Nasional Plus Jembatan Budaya. Jurnal Program Pascasarjana Universitas Pendidikan Ganesha Program Studi Pendidikan Matematika. Volume 2.

Devi, P., K. (2010). Keterampilan Proses dalam Pembelajaran IPA. Jakarta: PPPPTK IPA.

Djamarah dan Bukhari. (2000). Guru dan Anak Didik dalam Interaksi edukatif Suatu Pendekatan Teoritis Psikologi. Jakarta: Renika Cipta.

Gunada, W.I., Sahidu, H., dan Sutrio, S. (2015). Pengembangan Perangkat Pembelajaran Fisika Berbasis Masalah untuk Meningkatkan Hasil Belajar dan Sikap Ilmiah Mahasiswa. Jurnal Pendidikan Fisika dan Teknologi. 1(1), 38-46.

Handhika, J. (2010). Pembelajaran Fisika Melalui Inkuiri Terbimbing dengan Metode Eksperimen dan Demonstrasi Ditinjau dari Aktivitas dan Perhatian Mahasiswa. JP2F. 1(1), 9-23.

Herayanti, L., Habibi. (2014). Model Pembelajaran Berbasis Masalah dengan Pendekatan Inkuiri untuk Meningkatkan Kreativitas Calon Guru Fisika. Jurnal Kependidikan. 13(3), 281-287.
Hosnan. (2016). Pendekatan Saintifik dan Kontekstual dalam Pembelajaran Abad 21. Bogor: Ghalia Indonesia.

Ismaimuza, D., (2011). Kemampuan Berpikir Kritis Matematis Ditinjau dari Pengetahuan Awal Siswa. Jurnal Pendidikan Matematika, 2(1), 11-20.

Irawati. R.,K. (2014). Pengaruh Model Problem Solving dan Problem Posing serta Kemampuan Awal terhadap Hasil Belajar Siswa. Jurnal Pendidikan SAINS, 2(4), 184192.

Masek, A., Sulaiman, Y. (2011). The Effect of Problem Based Learning on Critical Thinking Ability: A Theoretical and Empirical Review. International Review of Social Sciences and Humanities, 2(1). 215221.

Meyers, B.E., Washburn, S.G. \& Dyer, J.E. (2004). Assessing Agriculture Teacher' Capacity for Teaching Science Integrated Process Skills. Journal of Southern Agricultural Education Research, 54 (1), 74-84.

Muamar, H., Hardjono, A., Gunawan, G. (2015). Pengaruh Model Pembelajaran Assure dan Pengetahuan Awal Terhadap Hasil Belajar IPA-Fisika Siswa Kelas VIII SMPN 22 Mataram. Jurnal Pendidikan Fisika dan Teknologi, 1(3), 166-172.

Prastiti, T., D. (2007). Pengaruh Pendekatan Pembelajaran RME dan Pengetahuan Awal Terhadap Kemampuan Komunikasi dan Pehamanan Matematika Siswa SMP Kelas VII. Didaktika, 1(1), 199-215.

Prihatiningtyas, S., Prastowo, T., \& Jatmiko, B. (2013). Imlementasi Simulasi PhET dan Kit Sederhana untuk Mengajarkan Keterampilan Psikomotor Peserta didik pada Pokok Bahasan Alat Optik. Jurnal Pendidikan IPA Indonesia. 2(1).

Prima, E.C., \& Kurniawati, I., (2011). Penerapan Model Pembelajaran Problem Based Learning dengan Pendekatan Inkuiri untuk Meningkatkan Keterampilan Proses Sains dan Penguasaan Konsep Elastisitas pada Siswa SMA. Jurnal Pendidikan MIPA, 16(1), 179-184.

Rahmawati, D., Nugroho, S.E., \& Putra, N.M.D (2014). Penerapan Model Pembelajaran kooperatif Tipe Numbered Head Together Berbasis Eksperimen Untuk Meningkatkan 
Keterampilan Proses Sains Sains Siswa SMP. UPEJ, 3(1), 41-45.

Sani, R.A. (2014). Pembelajaran Saintifik untuk Implementasi Kurikulum 2013. Jakarta: Bumi Aksara.

Setyowati, A., dan Subali, B. (2011). Implementasi pendekatan konflik kognitif dalam pembelajaran fisika untuk menumbuhkan kemampuan berpikir kritis siswa SMP kelas VIII. Jurnal Pendidikan Fisika Indonesia, 7(2), 89-96.

Suardani, N.N., Swasta, I.B.J., dan Widiyanti, N.L.P.M. (2014). Pengaruh Model Pembelajaran Berbasis Masalah terhadap Kemampuan Pemecahan Masalah dan Keterampilan Proses Sains Siswa. Jurnal Program Pascasarjana Universitas Pendidikan Ganesha Program Studi Pendiidkan IPA. 4(1).

Suliyono, (2013). Pengaruh Pendekatan Genius Learning Berbasis Kerja Imiah terhadap
Prestasi Belajar Fisika Ditinjau dari Pengetahuan Awal Sis SMPN 13 Balikpapan Tahun 2012. Jurnal Pendidikan SAINS, 1(3), 243-248.

Sundayana, R. (2014). Statistika Penelitian Pendidikan. Bandung: Alfabeta.

Trianto. 2007. Model-model Pembelajaran Inovatif Berorientasi Konstruktivistik. Jakarta: Prestasi Pustaka Publisher.

Wahyudi, A., Marjono, dan Harlita. (2015). Pengaruh Problem Based Learning terhadap Keterampilan Proses Sains dan Hasil Belajar Biologi Siswa Kelas X SMA Negeri Jumapolo Tahun Pelajaran 2013/2014. Jurnal Bio-Pedagogi. 4 (1), 5-11.

Widayanto. (2009). Pengembangan Keterampilan Proses dan Pemahaman Siswa Kelas X Melalui KIT Optik. Jurnal Pendidikan Fisika Indonesia, 5(2), 1-7. 